\title{
Isomerization Reactions of Cyclohexene over Molten Salt Catalysts
}

\author{
Yohji Nakatsuji*, Kunio Shigeta*, Masakatsu Nomura* and Shōichi Kikkawa* \\ We have already reported that catalytic activity for hydrocracking of polyaromatic com- \\ pounds of $\mathrm{ZnCl}_{2}-\mathrm{CuCl}$ binary melts is more outstanding than that of $\mathrm{ZnCl}_{2}$ melt alone. In \\ order to further study the catalytic activity of these melts, isomerization of cyclohexene at $400^{\circ} \mathrm{C}$ \\ using a continuous flow method was carried out. $\mathrm{ZnCl}_{2}$ melt showed only $2 \%$ conversion \\ while a $\mathrm{ZnCl}_{2}-\mathrm{CuCl}$ melt containing $30 \mathrm{~mol} \%$ of $\mathrm{CuCl}$ realized as high as $43.7 \%$ conversion. \\ These observations strongly suggest that some active species formed in the binary melts effec- \\ tively enhance the isomerization reaction.
}

\section{Introduction}

Kenney et al. ${ }^{1)}$ found that the catalytic activity of molten $\mathrm{ZnCl}_{2}$ for the elimination of hydrogen chloride from isopropyl chloride was lowered by addition of metal chlorides, such as $\mathrm{KCl}, \mathrm{NaCl}$, and AgCl. Through intensive studies of catalytic activities of $\mathrm{ZnCl}_{2}$-containing melts for some organic reactions ${ }^{2}$ including hydrocracking of coal related substances ${ }^{3,4)}$, we found a remarkable catalytic activity of binary molten mixtures of $\mathrm{ZnCl}_{2}$ and $\mathrm{CuCl}$ when it was compared with that of $\mathrm{ZnCl}_{2}$ alone. In order to study this observation further in detail, we carried out isomerization of cyclohexene over molten salts.

\section{Results and Discussion}

The results observed are shown in Table 1 . A small quantity of the proton source $\left(\mathrm{H}_{2} \mathrm{O}, \mathrm{HCl}\right)$ existing in the reaction system acts as a co-catalyst for Lewis acid in the isomerization of cyclohexene to methylcyclopentenes that proceeds via the carbonium ion mechanism. Accordingly, the total yield of isomerized products (1-methylcyclopentene, 3-methylcyclopentene, methylcyclopentane, and 1chloro-1-methylcyclopentane) could be a measure of the acid strength of the molten salts. The yield of 1-methylcyclopentene was always higher than that of 3-methylcyclopentene because of the stability of the carbonium ion formed in the course of reaction. The ratio of 1-methylcyclopentene/3methylcyclopentene was in the range of 3.5-5.5 (in Runs 2-8).

Runs $1-8$ revealed the influence of composition of $\mathrm{ZnCl}_{2}-\mathrm{CuCl}$ melts on product distribution. The

Received March 17, 1980

* Department of Applied Chemistry, Faculty of Engineering, Osaka University (Yamadakami, Suita, Osaka 565) addition of $\mathrm{CuCl}$ to $\mathrm{ZnCl}_{2}$ raised the catalytic activity, and the extent of isomerization varied remarkably depending upon the composition-change in the molten salt. The melt of $\mathrm{ZnCl}_{2}: \mathrm{CuCl}=$ $70: 30$ (Run 4) gave the maximum yield of isomerized products. This increase in catalytic activity by addition of $\mathrm{CuCl}$ to $\mathrm{ZnCl}_{2}$ seems to indicate the presence of new active species.

The detection of $\mathrm{HCl}$ addition products (chlorocyclohexane and 1-chloro-1-methylcyclopentane) led us to examine the influence of $\mathrm{HCl}$ on the isomerization (in Runs 9 and 10). The addition of hydrogen chloride to the reaction system increased the yields of isomerized products as expected; the addition of large amounts of $\mathrm{HCl}$ increased the yields of addition products remarkably. These findings indicate that the cause of rise in the catalytic activity by addition of $\mathrm{CuCl}$ to $\mathrm{ZnCl}_{2}$ is not attributable to the change in the amounts of proton sources in the reaction system.

The catalytic activity of $\mathrm{ZnCl}_{2}$ for several acidcatalyzed reactions ${ }^{1), 5)}$ is lowered by addition of alkali metal chlorides because of the formation of some stable complex salts. Runs 11 and 12 showed the influence of addition of the alkali metal salts on the catalytic activities of the binary molten salts. In comparison with the result of Run 5, the addition of $\mathrm{KCl}$ or $\mathrm{LiCl}$ lowered the yields of isomerized products. The extent of the lowering of the catalytic activity was greater with $\mathrm{ZnCl}_{2} / \mathrm{CuCl} / \mathrm{KCl}$. $\mathrm{ZnCl}_{2}$ salts tend to form stable complex ions with $\mathrm{KCl}$ more than $\mathrm{LiCl}$ because the partial interaction between small $\mathrm{Li}^{+}$and $\mathrm{Cl}^{-}$ is very strong in LiCl. These results can not be explained by diluent effect and would demonstrate the destraction of the active species resulting from the interaction of $\mathrm{ZnCl}_{2}$ and $\mathrm{CuCl}$.

The Hammett indicator $\operatorname{method}^{7}$ and the IR method using xanthone ${ }^{8)}$ did not show any dif- 
Table 1 Product Distribution of Isomerization of Cyclohexene

\begin{tabular}{|c|c|c|c|c|c|c|c|c|c|c|c|c|}
\hline Run No. & 1 & 2 & 3 & 4 & 5 & 6 & 7 & 8 & 9 & 10 & 11 & 12 \\
\hline \multirow{2}{*}{$\begin{array}{l}\text { Molten Salt } \\
\text { Composition }\end{array}$} & \multirow{2}{*}{$\mathrm{ZnCl}_{2}$} & \multicolumn{7}{|c|}{$\mathrm{ZnCl}_{2}: \mathrm{CuCl}^{\mathrm{CuC}}$} & \multirow{2}{*}{$\left.\mathrm{ZnCl}_{2}{ }^{\mathrm{a}}\right)$} & \multirow{2}{*}{$\mathrm{ZnCl}_{2}{ }^{\mathrm{b}}$ ) } & \multirow{2}{*}{$\begin{array}{c}\left.\mathrm{ZnCl}_{2} \mathrm{c}\right) \\
/ \mathrm{CuCl} \\
/ \mathrm{KCl}\end{array}$} & \multirow{2}{*}{$\begin{array}{c}\left.\mathrm{ZnCl}_{2} \mathrm{c}\right) \\
/ \mathrm{CuCl} \\
/ \mathrm{LiCl}\end{array}$} \\
\hline & & $90: 10^{\mathrm{d})}$ & $80: 20$ & $70: 30$ & $60: 40$ & $50: 50$ & $40: 60$ & $30: 70$ & & & & \\
\hline Recovery $(\%)$ e) & 73.5 & 89.2 & 96.8 & 88.5 & 79.2 & 88.0 & 87.6 & 91.4 & 85.9 & 107.9 & 87.8 & 79.0 \\
\hline Yield $\left.(\%)^{\mathrm{f}}\right)$ & 2.0 & 4.3 & 11.8 & 43.7 & 29.3 & 25.9 & 19.5 & 13.4 & 2.8 & 9.8 & 1.4 & 8.6 \\
\hline & 1.5 & 3.4 & 9.3 & 32.0 & 22.0 & 18.5 & 16.4 & 10.5 & 2.1 & 5.5 & 1.2 & 6.7 \\
\hline & $\mathrm{tg})$ & 0.8 & 2.2 & 8.5 & 5.7 & 5.3 & 3.0 & 2.1 & 0.6 & 1.1 & $\mathrm{t}$ & 1.2 \\
\hline & $\mathrm{t}$ & $\mathrm{t}$ & $\mathrm{t}$ & 2.2 & 0.8 & 1.5 & $\mathrm{t}$ & 0.5 & $\mathrm{t}$ & $\mathrm{t}$ & $\mathrm{t}$ & $\mathbf{t}$ \\
\hline & 97.4 & 95.1 & 87.4 & 51.5 & 68.2 & 71.0 & 79.3 & 85.4 & 94.0 & 36.1 & 98.1 & 90.3 \\
\hline $\begin{array}{l}\mathrm{Me} \\
\mathrm{Cl}\end{array}$ & - & - & - & 0.8 & 0.8 & $\mathrm{t}$ & $\mathrm{t}$ & $\mathrm{t}$ & $\mathrm{t}$ & 3.1 & $\mathrm{t}$ & 0.6 \\
\hline & 0.6 & 0.6 & 1.2 & 0.9 & 0.9 & 1.0 & $\mathrm{t}$ & 0.5 & 1.3 & 50.4 & $\mathrm{t}$ & 0.9 \\
\hline Others $^{\mathrm{h}}$ ) & - & - & - & 3.9 & 1.5 & 2.1 & 0.9 & 0.7 & 1.9 & 3.7 & - & $\mathrm{t}$ \\
\hline
\end{tabular}

Reaction conditions : Temperature $400^{\circ} \mathrm{C}$, Cyclohexene $0.068 \mathrm{~mol} / \mathrm{hr}, \mathrm{Ar} 0.089 \mathrm{~mol} / \mathrm{hr}$; a) $\mathrm{HGl} \mathrm{gas}(0.019 \mathrm{~mol} / \mathrm{hr}$ ) was bubbled for $1 \mathrm{hr}$ before reaction. b) $\mathrm{HCl}$ gas $(0.019 \mathrm{~mol} / \mathrm{hr})$ was added to the reaction system. c) $48: 32$ : 20 d) $\mathrm{mol} \%: \mathrm{mol} \%$ e) (weight of recovered compounds/weight of feed) $\times 100$ f) Total yield of isomerized products $\mathrm{g}$ ) " $\mathrm{t}$ " indicates the yield being less than $0.5 \%$. h) Higher boiling products

ference of the observed acid strength between $\mathrm{ZnCl}_{2}$ alone and the binary mixture of $\mathrm{ZnCl}_{2}$ and $\mathrm{GuCl}$ in solid state.

\section{Experimental}

1) Materials Zinc chloride, copper(I) chloride, potassium chloride, and lithium chloride all obtained from Nakarai Chemicals, Ltd. were guaranteed reagents. The cyclohexene (G. R.) obtained from Wako Pure Chemical Industries, Ltd. was used without further purification after its purity was found satisfactory by GLC.

2) Apparatus and procedure The bubbler type reaction apparatus and the procedures used in the experiments were reported in detail in our previous paper ${ }^{9}$. The molten salt was dried for $1 \mathrm{hr}$ in the argon atmosphere. Cyclohexene was introduced into the vaporizer with a microfeeder and it was then bubbled along with a stream of argon into the molten salt. The product distribution was determined by GLG (Shimadzu GG4 BPTF, $4.5 \mathrm{~m} \times 3 \mathrm{~mm}$ column packed with $20 \%$ SE-30 on Uniport B 60-80 mesh, $30-270^{\circ} \mathrm{C}, 5$ ${ }^{\circ} \mathrm{C} / \mathrm{min}$, TCD, $\mathrm{H}_{2}$ carrier). Mass spectra of all products were obtained by means of GC-MS. 1Methylcyclopentene and 3-methylcyclopentene were isolated by preparative GLC and identified by ${ }^{1} \mathrm{H}$ and ${ }^{13} \mathrm{G}$ NMR spectra. Small quantities of benzene and 1,3-cyclohexadiene, which were dehydrogenated products of cyclohexene, were found in all runs. Also only small amounts of gaseous products were observed.

\section{References}

1) Kenney, C. N., Takahashi, R., J. Catal., 22, 16 (1971).

2) Kikkawa, S., Nomura, M., Yuki Gosei Kagaku, 33, 593 (1975).

3) Nakatsuji, Y., Fujioka, S., Nomura, M., Kikkawa, S., Bull. Chem. Soc. Jpn., 50, 3406 (1977).

4) Nakatsuji, Y., Kubo, T., Nomura, M., Kikkawa, S., Bull. Chem. Soc. Jpn., 51, 618 (1978).

5) Kikkawa, S., Hayashi, T., Yamada, T., Kogyo Kagaku Zasshi, 74, 1818 (1971).

6) Tanabe, K., Takeshita, T., "San Enki Shokubai" 1st ed. p 106, Sangyo Tosho (1975).

7) Hawke, D. L., Steigman, J., Anal. Chem., 26, 1989 (1954).

8) Cook, D., Can. J. Chem., 41, 522 (1963).

9) Kikkawa, S., Nomura, M., Ikezaki, M., Nippon Kagaku Kaishi, 1976, 472. 
要旨

溶融塩触媒を用いたシクロヘキセンの異性化反応

中辻 洋司*, 重田 邦男*, 野村 正勝*, 吉川 彰一*

著者らはすでに多環芳香族化合物 の水素化分解において, $\mathrm{ZnCl}_{2}-\mathrm{CuCl}$ の 2 元系溶融塩が $\mathrm{ZnCl}_{2}$ 単独の溶融塩触媒に比


元系溶融塩の触媒活性上昇の要因をさぐる一つの手段として, 本論文ではシクロヘキセンの異性化反応を検討した。反応はシ クロヘキセンをアルゴンガスと共に気相で $400^{\circ} \mathrm{C}$ に加熱した 溶融塩中にふき込んで行う流通法によった。生成物は1-メチ ルシクロペンテン，3-メチルシクロペンテン，メチルシクロペ ンタン拈よび 1-クロロ-1-メチルシクロペンタンで 1-メチル シクロペンテンが主要生成物であることやこれまでの結果か ら，本反応はカルボニウムイオン機構で進むと考えられる。こ こではこれらの 4 つの生成物の総和を転化率としたが，これは

$*$ 大阪大学工学部応用化学教室 (565 吹田市山田上)
溶融塩媒体の本反応に対する活性の尺度ともなる。生成物中に $\mathrm{HCl}$ の付加物と考えられる 1-クロロ-1-メチルシクロペンタ ンを認めたので, $\mathrm{ZnCl}_{2}$ 中で $\mathrm{HCl}$ 共存下に反応を行ったとこ ろ, 上記化合物の他に多量のクロロシクロヘキサンが生成し た。Table 1 から明らかなように, $\mathrm{ZnCl}_{2}-\mathrm{CuCl}$ の組成を変 化させると転化率は著るしく变動し， $\mathrm{ZnCl}_{2}-\mathrm{CuCl}$ が $7: 3$ のモル比の時最も高い転化率 $43.7 \%$ を示した。このことは $\mathrm{ZnCl}_{2}$ に CuCl を添加することにより本反応を促進する活性 種が新たに生成していることを強く示唆する。しかし固体状態 の $\mathrm{ZnCl}_{2}$ 抢よび $\mathrm{ZnCl}_{2}-\mathrm{CuCl}$ 塩のハメット指示薬7) やキサ ントンを用いる IR 法等8) による酸強度の測定を行ったが両者 の間に何ら差異がみられなかった。

\section{Keywords}

Isomerization, Gyclohexene, Molten salt catalyst, Zinc chloride, Cuprous chloride 